\title{
Den franske præsident og EU-formandskabet
}

\section{Ulla Holm}

\section{Det franske formandskab har været exceptionelt og en historisk begivenhed. Sarkozy har sat EU i bevægelse og Frankrig i førersædet}

Hvem er gaullisten Sarkozy? Er hans hyper-aktivisme positiv eller negativ for det franske EU-formandskab? Vil Sarkozy være i stand til at sætte franske nationale interesser på standby, hvad et EU-formandskab kræver? Hvad betyder det for EU, når Sarkozy konstant taler om nødvendigheden af 'brud'?

Sådan lød de ængstelige spørgsmål i de europæiske hovedstæders regeringskontorer, da Sarkozy overtog EU-formandskabet den 1. juli 2008. Sarkozy gjorde denne ængstelse til skamme under finanskrisen og konflikten mellem Georgien og Rusland. Sarkozy fremstod som den store leder af et handlekraftigt EU.

Fransk synlighed og handlekraft i EU og i verden er et 'must' i den franske nationalstatslige selvforståelse. Sarkozy repræsenterede dermed ikke et brud med fortidens franske aktivistiske europapolitik. Han fort- sætter i de Gaulles og Mitterrands europæiske fodspor. EU fremstilles stadig som mangedobling af magt og som et middel til at spille en vigtig udenrigspolitisk rolle.

\section{Brug for pragmatisme}

Stor var den europæiske ængstelse, da Sarkozy lige efter det irske nej til Lissabon-traktaten 12. juni 2008 - få uger før det franske EU-formandskab - udtalte, at irerne igen måtte gå til stemmeurnerne for at stemme ja. Det blev taget ilde op, at netop en fransk præsident kom med en sådan udtalelse. Franskmændene havde jo selv ved en folkeafstemning i 2005 sagt nej til den europæiske forfatningstraktat.

Ville den franske præsident nu belære andre nationalstaters befolkninger om, hvordan de skulle opføre sig? Men Sarkozy besindede sig 
hurtigt. Efter den uheldige udtalelse lød det fra Sarkozy, at nu måtte alle regeringsledere tage EU-borgernes daglige bekymringer alvorlig. 'Back to basics', lød det fra Frankrig. Sarkozy ville, at den økonomiske og sociale situation i EU skulle tackles på en effektiv og pragmatisk måde.

Den europæiske bekymring over risikoen for fransk arrogance under EU-formandskabet blev taget alvorligt af de franske parlamentarikere og af regeringen. I oktober 2007 barslede det franske parlaments udenrigspolitiske kommission med en rapport, der gjorde opmærksom på, at nok var Frankrig respekteret af de andre EU-lande, men samtidig mistænktes landet for ikke altid at overholde EU-spilleregler.

Ifølge rapporten var det derfor vigtigere end nogensinde før, at det franske formandskab opførte sig eksemplarisk.

Rapporten advarede mod, at Frankrig under sit EU-formandskab kun lytter til andre store EU-lande, hvad Frankrig har haft en tilbøjelighed til at gøre. Ifølge rapporten udelukkede en eksemplarisk adfærd dog ikke et stærkt lederskab - især i kritiske situationer; men lederskabet skulle ske i samråd med de andre lande.

Som optakt til det franske EU-formandskab udgav en statslig kommission en hvidbog om Frankrig og Europa i verden - 2008 - 2020. Den anbefaler en pragmatisk politik, som tager udgangspunkt i konkrete projekter. Ifølge hvidbogen kræver en sådan politik, at Frankrig antager 'en mindre deklaratorisk adfærd og en mere operationel politik'.

\section{Fransk lydhørhed}

Sarkozy tog i en vis udstrækning disse råd ad notam. Der skulle lyttes til EU-medlemsstaternes forskellige interesser. Sarkozy og ministrene kastede sig derfor ud i et heftigt rejsediplomati i 2007. Oplægget til det franske EU-formandskab blev - lige som under andre EU-formandskaber - udarbejdet i nøje samråd med de to følgende formandskaber (Tjekkiet og Sverige) og med de to foregående - i dette tilfælde med Tyskland og Portugal.

Hovedprioriteterne for fransk EUformandskab blev udpeget til at være: migration, klima-energi, sikkerhed - og forsvar samt etableringen af en Middelhavsunion. Desuden skulle Lissabon-traktatens fremtid, Lissabon-strategien for vækst og jobskabelse samt 'sundhedstjekket' af den fælles landbrugspolitik også stå på dagsorden.

Fælles for de udvalgte politikområder er, at de alle fokuserer på EU's interne og eksterne sikkerhed. Der blæses til kamp mod illegal indvandring, mod $\mathrm{CO}_{2}$ udslip, mod afhængighed af olie, mod kriser/krige uden for EU-medlemsstaternes grænser samt mod det sydlige Middelhavs voksende økonomiske, sociale, politiske og religiøse problemer. Sarkozys europæiske ambition har 
været, at der skal handles så hurtigt som muligt mod disse trusler med en blanding af dramatisering og pragmatisme.

\section{Nutid og fremtid}

Aktivistisk rastløshed, viljen til at lancere en endeløs række af konkrete reformforslag og dramatiseringen af disse reformer både internt $\mathrm{i}$ Frankrig og eksternt på den europæiske og internationale scene - er kernen i Sarkozys politiske stil. En stærk præsident, som genindfører styrke, styring, orden og autoritet, skal sikre, at Frankrig igen kan blive en stærk nationalstat, som projicerer sig ud i Europa og i verden.

Dramatiseringen tjener det politiske formål at vække franskmændene og EU til dåd efter lang tids politisk passivitet under tidligere præsident Jacques Chiracs sidste præsidentperiode (2002 - 2007). Sarkozy taler om, at der over alt er en uopsættelig nødvendighed for reformer. Udenrigsminister Bernard Kouchner, tidligere socialist og grundlægger af Læger uden grænser, startede sit job som udenrigsminister med at erklære, at han opfattede sit udenrigsministerium som 'Ministeriet for uopsættelige handlinger'.

Under præsidentvalgkampagnen henviste Sarkozy ofte til forskellige aspekter af fransk historie for at forsikre befolkningen om, at han ville være i stand til at samle venstrefløjens og højrefløjens helte i sin per- son. Han alene kunne indgive Frankrig håb om at komme ud af det politiske og økonomiske morads, landet havde befundet sig i under Chirac.

Det var derfor ikke tilfældigt, at Sarkozy fremstillede sig som en reinkarnation af de Gaulle, der satte en stopper for Algeriet-krigen (1954 1962) og dermed reddede Frankrig fra totalt kaos. Ifølge Sarkozy var "General de Gaulle håbets symbol. Da alt var tabt, fik de Gaulle franskmændene til at håbe igen. Jeg holder af Frankrig, og jeg vil indgive franskmændene håb”.

Efter præsidentvalget har Sarkozys taler imidlertid været præget af næsten kemisk renselse for referencer til fortiden. Væk er henvisningerne til fransk gloire og grandeur (ære og storhed) og historiske fyrtårne.

Fremtiden skal tilsyneladende skabes uden relationer til fortiden, som ikke kan bruges til noget i 'det store spring' fremad. Sarkozy vil fremstå som nutidens og fremtidens mand. Han vil, at "Frankrig står i spidsen for de lande, som skaber historien og ikke underlægger sig den”. (Sarkozys tale til de franske ambassadører den 27. august 2008).

Manglen på referencer til fransk fortid får Sarkozy til at fremstå som bruddets mand. Men fortiden indhenter ham alligevel, når han understreger, at Frankrig skal skabe historie, være primus inter pares i EU, og være "sjælen i den nye europæiske renæssance, som verden har 
brug for og være bærer af budskabet om menneskerettigheder" (Sarkozys nytårstale 2008). Frankrig kan i denne optik stadig noget, som andre (små) lande ikke kan: Spille en afgørende politisk rolle i EU, og EU skal være en synlig og aktivistisk aktør.

En sådan vision ligger i direkte forlængelse af tidligere præsidenters opfattelse af Frankrig i EU og i verden. Denne vision har dog udmøntet sig i forskellige opfattelser af forholdet mellem EU og Frankrig. De Gaulle opererede således med et staternes EF, hvor de store stater indgik i forskellige alliancer alt efter den konkrete situations muligheder dog altid med den fransk-tyske akse som omdrejningspunkt.

Mitterrand var fortaler for en fordobling af Frankrig på EU-niveau, idet EU skulle kunne alt det, som Frankrig ikke længere kunne - men stadig med den fransk-tyske akse som kernen i EU-konstruktionen. Chirac blandede de to afdøde præsidenters visioner i sin EU-politik. Det samme gør Sarkozy. Hans politik er en blanding af alliancepolitik mellem store magter og en fordobling af Frankrig på EU-niveau.

I begge tilfælde forbliver den fransk-tyske akse kernen. Dog er der sket en vis forskydning af den fransk-tyske akses centralitet. Sarkozy har flere gange udtalt, at den fransk-tyske akse er én af hjørnestenene i europæisk politik pga. den store udvidelse i 2004. En anden akse er det fransk-engelske forsvarssamarbejde. Når der opstår kriser i Europa, er det dog stadig den fransk-tyske akses samarbejde, der tæller som under den nuværende finanskrise og Georgien-konflikten.

\section{Sarkozy i europæisk statsmandstøj}

"I dag er Frankrig inde i hjertet af EU, og vi arbejder kollektivt sammen med de andre EU-medlemsstater" (Sarkozys tale til de franske ambassadører d. 27. august 2008).

Sarkozy har ofte udtalt, at han vil et nyt Europa - et brud med fortidens europapolitik. Samtidig taler han også om nødvendigheden af en pragmatisk europapolitik, hvor de konkrete små skridt hen imod 'et resultaternes Europa' skal have topprioritet.

Sarkozy vil et pragmatisk brud! Dette begreb har tilsyneladende en indbygget selvmodsigelse. Der er ikke tale om et 'revolutionært' brud med de Gaulles, Mitterrands eller Chiracs europapolitik. Bruddet henviser til opgør med Chiracs EU-politik, som ifølge Sarkozy satte Frankrig på den europæiske sidelinje. Bruddet er et positioneringsbrud i forhold til Chiracs politik.

Begrebet 'pragmatisme' refererer til måden at føre politik på. Som anbefalet i den ovenfor omtalte parlamentsrapport skal det være slut med de store retoriske armbøjninger og begrebsgymnastikken. Der skal tales jævnt og forståeligt om hverdagspro- 
blemer, og der skal laves kompromiser i EU.

Sarkozy kan have besvær med at huske formaningen om at holde lav fransk profil og være pragmatisk. I foråret $2008 \mathrm{kom}$ han eksempelvis for skade at sige, at den europæiske ambition er en forlængelse af den franske ambition.

Det kunne nok få det til at løbe koldt ned ad ryggen på Merkel og de andre europæiske statsledere. En sådan udtalelse kunne ses som et udtryk for Sarkozys opfattelse af EU som en fordobling af Frankrig og dermed tilsidesættelse af andre landes europavisioner. Efter den lapsus er den tydelige tale om en forlængelse af den franske have forstummet. Men det betyder ikke, at Sarkozy har opgivet den 'mitterrandske' vision om, at EU skal kunne alt det, som Frankrig ikke længere kan. EU skal især føre en fælles pengeog valutapolitik, som tager hensyn til vækst og beskæftigelse.

\section{Arven fra Mitterrand}

Da Mitterrand i 1991-1992 forhandlede Maastricht-traktaten sammen med daværende kansler Helmuth Kohl, foreslog Mitterrand oprettelsen af en europæisk økonomisk regering, som skulle fastlægge de generelle retningslinjer for EU's penge- og valutapolitik og for medlemsstaternes finanspolitik. Frankrig måtte dog afstå fra dette krav; men det har ikke forhindret de franske præsidenter i at fortsætte kritikken af Centralbankens penge- og valutakurspolitik samt af Vækst- og Stabilitetspagten, der sætter snævre grænser for eurolandenes statslige underskud.

Sarkozy er fulgt i samme spor lige fra præsidentdag et. Den franske ide om en økonomisk regering og et handlekraftigt EU fik vind i sejlene, da finanskrisen tordnede ind på EUscenen. På de forskellige topmøder om finanskrisen, som Sarkozy indkaldte til, plæderede han for oprettelsen af en økonomisk regering med udgangspunkt i eurogruppen, der ifølge Sarkozy fremover bør holde faste topmøder med de 15 (efter 1.1.09 16, red) eurolande, dvs. de lande der har tilsluttet sig den økonomiske og monetære union.

Hvis det franske EU-formandskab får opbakning til dette forslag, er der blevet skabt lydhørhed for Mitterrands oprindelige ide om oprettelse af en økonomisk regering.

Sarkozys første handling i finanskrisen var at indkalde de store stater - Tyskland, Storbritannien og Italien til det såkaldte G4 mini-topmøde den 4. oktober. Dog sørgede han for, at mødet blev europæisk indrammet af Barroso, formanden for Europa-Kommissionen, Jean-Claude Juncker, lederen af Euro-gruppen, samt Jean-Claude Trichet, direktøren for Den Europæiske Centralbank. Sarkozys mødeindkaldelse huede bestemt ikke de andre EU-medlemsstater, som frygtede, at Frankrig 
ville presse sine egne løsningsforslag igennem.

Den franske finansminister Christine Lagarde gjorde ikke bekymringen til skamme, da hun luftede ideen om oprettelsen af en fælles europæisk indskudsfond, der skulle komme betrængte banker til hjælp. Det forslag blev skudt i sænk med det samme af den tyske kansler og den engelske premierminister Gordon Brown. Sarkozy måtte offentligt tage kraftigt afstand fra sin egen ministers udtalelse for ikke at støde de to andre store europæiske magter.

Et kompromis blev nået og derefter blev eurogruppen og Storbritannien indkaldt til et møde, hvor man tog beslutning om en samordnet handlingsplan, der udløste en række statsstyrede redningsplaner for de trængte banker.

Kompromiset var en kombination af nationale handlingsplaner og EUovervågning af udviklingen. Planen blev hilst med tilfredshed på det europæiske topmøde den 15 . - 16. oktober. Den bliver fulgt op med et møde i Washington i november - efter det amerikanske præsidentvalg.

Det er meningen, at Sarkozy som leder af EU-formandskabet, kommissionsformand Barroso, G8 (de største industrilande), samt Brasilien, Indien, Kina og Rusland skal diskutere, hvordan man på globalt plan kan samordne initiativer, der kan imødegå finanskrisen og den globale økonomiske recession, der truer forude. De store lande og regi- onale magter, der opererer på globalt niveau, skal mobiliseres hurtigt. I sin tale til de franske ambassadører i august 2008 erklærede Sarkozy, at "hvis vi ikke gør noget snarest muligt så vil finanskrisen betyde, at EU kommer økonomisk bagud i forhold til de store opkommende magter".

\section{Georgien}

Sarkozy reagerede også lynhurtigt over for Ruslands invasion i Georgien. På få dage fik han skabt enighed mellem EU-landene om en fælles tilgang til Georgien-konflikten. Det skete på trods af EU-landenes splittede holdning til Rusland. Det 'nye Europa' - de tidligere østeuropæiske lande og de baltiske lande - var af historiske grunde imod en blød linje over for Rusland. De ønskede en hård sanktionspolitik over for Rusland. Tyskland, Italien og Frankrig gik derimod ind for en kritisk og pragmatisk dialog med såvel Rusland som Georgien.

Sarkozys og udenrigsminister Kouchners intense penduldiplomati gav pote. EU-medlemsstaterne, Georgien og Rusland skrev under på en sekspunkt-plan. Rusland og Georgien indgik derefter våbenhvile.

Standsningen af russernes fremmarch - uden amerikansk indblanding - blev fremstillet som et bevis på, at EU endelig var i stand til at optræde som sikkerhedsproducent til trods for, at Lissabon-traktaten 
ikke var blevet vedtaget. Traktaten ville have betydet udnævnelse af en EU-udenrigsminister og et mere permanent EU-formandskab (to et halvt år med mulighed for forlængelse).

Sarkozy var da heller ikke sen til at udtale lige efter indgåelsen af våbenhvilen, at hvis Lissabon-traktaten havde været på plads, ville EU have kunnet tale med én stemme. Da det nu ikke var tilfældet, var Frankrig nødt til at tage initiativ og derefter diskutere indholdet af sekspunkt planen med de andre europæiske lande.

Hvis ikke Rusland og Georgien havde indgået en våbenhvile, ville det franske initiativ givetvis have vakt stor irritation blandt de andre EU-lande. De ville have opfattet Frankrig, som det land der altid vil føre sig frem uden at have lyttet til alle andre, inden der blev taget en beslutning. Nu lykkedes det imidlertid Frankrig at hale en foreløbig succes i land, som giver fransk EUformandskab prestige.

De lynsnare redningsaktioner over for finanskrisen og krigen i Georgien viste Sarkozys/Frankrigs handlingskraft og synlighed. Aktionerne bekræftede den franske selvforståelse om 'at handle er at eksistere', som Mitterand udtalte i 1986.

Sarkozys håndtering af finanskrisen og Georgien-konflikten er en illustration af blandingen af gaullistisk og mitterrandsk europapolitik. Sarkozy samarbejder på gaullistisk vis med andre vigtige europæiske stater samtidig med, at han fortsætter den mitterrandske vision om et Frankrig, der som en synlig og effektiv aktør fordobles på EU-niveau.

Sarkozy balancerer på en knivskarp æg mellem de to politikker. Hvis han spiller de store magters kort i for lang tid, vil mindre og små europæiske magter anklage ham for udelukkende at forfølge fransk national storhed på bekostning af det europæiske sammenhold. I tilfælde af kriser ligger det imidlertid til højrebenet, at nogle store lande tager initiativer i et EU med 27 medlemsstater, som vil have svært ved at finde et hurtigt fælles fodslag.

Når der bliver dekreteret krise og alarmtilstand i EU-landene, gives der mere plads til, at enkelte lande tager ekstraordinære initiativer, som Sarkozy gjorde. Sådanne initiativer kan kun accepteres på længere sigt, hvis der indgås kompromiser med de andre EU-lande.

\section{Handlingsplan for klima og energi}

Det lykkedes Sarkozy at tage initiativ og indgå kompromiser både $\mathrm{i}$ håndteringen af konflikten i Georgien og i finanskrisen. Kan det også lade sig gøre at finde fælles fodslag hvad angår klima-energi handlingsplanen, som er top-prioritet under det franske formandskab? Lykkes det Sarkozy at få modvillige lande, så som Italien, Tyskland og Polen, til at være med til at nedbringe $\mathrm{CO}_{2}$-ud- 
ledningen med de 20 procent, som er blevet besluttet?

Der er ingen tvivl om, at Sarkozy vil kæmpe hårdt for en klima-energi aftale til trods for finans- og økonomi-krisen. Han forsikrede på det europæiske topmøde i oktober 2008, at EU's overordnede målsætning skal fastholdes. En sådan udtalelse åbner for fleksible ordninger for hvert enkelt land, når blot det sker inden for rammerne af det overordnede mål. Hvis det lykkes for det franske formandskab at finde et forlig inden for de fastlagte overordnede rammer, vil det være en kæmpe sejr for Sarkozy. Han vil kunne sige, at det franske EU-formandskab klarede hele tre kriser i løbet af få efterårsmåneder. Han vil kunne erklære, at når Frankrig er i stand til at handle, sker der noget på den europæiske scene

\section{Frankrig er tilbage i Europa}

"Jeg mener, at der ikke kan eksistere noget starkt Frankrig uden Europa, lige så vel som et magtfuldt Europa ikke kan eksistere uden Frankrig... Den europaiske konstruktion er Frankrigs absolutte prioritet, for uden Europa vil Frankrig ikke vare $i$ stand til at yde et effektivt suar på tidens udfordringer" (Sarkozys tale til de franske ambassadører d. 27. august 2007).

"De europaiske befolkninger lider under en identitetskrise, som er forbundet med globalisering og markedsgørelse. Ordet 'protektionisme' skal derfor ikke vare bandlyst" (Sarkozy til Europa-Parlamentet, 13. november 2007).

"Frankrig er tilbage i Europa". Det erklærede Sarkozy selv samme dag, hvor han blev valgt til fransk præsident. Når nu han siger, at Frankrig er tilbage i Europa, hvilket Europa og hvilket Frankrig taler han om? Gamle gaullister og venstrefløjen mener, at det er et neo-liberalt EU, Sarkozy vil. Imidlertid har Sarkozy - lige siden sin præsidentvalgkampagne - slået fast med syvtommersøm, at han vil, at EU skal beskytte borgerne. Det er oplægget til det franske EU-formandskab et klart bevis på. Oplæggets titel er Frankrigs tilbagekomst $i$ Europa og et beskyttende Europa (l'Europe protection).

Sarkozy har udtalt, at sand liberalisme kun eksisterer i teorien, ikke i den virkelige verden. Hans devise er, at ideologi ikke dur til noget som helst. Han er pragmatikeren, der betragter virkeligheden som den er, og sådan som franskmændene ser virkeligheden' (tale til journalister d. 18. september 2007).

Virkeligheden er, at et flertal af franskmændene sagde nej til den europæiske forfatningstraktat $i$ 2005. De sagde nej, fordi de mente, at traktaten var for liberal, at den ville fremme udflytning af virksomhederne med endnu større arbejdsløshed til følge samt at udenlandske virksomheder ville styrte sig over det europæiske marked. Det er denne bekymring, Sarkozy tager politisk højde for, når han taler om et be- 
skyttende Europa. Nok udtaler Sarkozy, at han er pragmatiker, og at han vil brud med fortidens politik; men hans vision om et beskyttende Europa ligger i forlængelse af afdøde præsident Mitterrands ide om et stærkt Europa, der skal kunne alt det, Frankrig ikke længere selv kan.

Ideen om statslig politisk og økonomisk intervention er grundfæstet i fransk politisk kultur. Det er den også hos Sarkozy, ligegyldigt om han ønsker mindre stat på det nationalstatslige territorium. Mindre stat i Frankrig skal kompenseres med mere politisk og økonomisk interventionisme på EU-niveau. EU skal således være mangedobler af den magt, som fransk økonomi mangler.

\section{Klodernes økonomiske kamp}

Den økonomiske politik er sikkerhedspolitik som følge af globaliseringen, der truer Europa i 'klodernes økonomiske kamp'. Der skal gøres noget drastisk - og det skal ske hurtigt. Truslen om fransk/europæisk økonomis nedtur afspejles i Sarkozys sprog. Han taler om de globale finansielle rovdyr, som forhindrer en sund vareproduktion. Han advarer mod, at Europa bliver en ladeport for store udefra kommende magter som Kina, Indien og Brasilien.

Disse globale giganter må ikke dumpe deres varer inden for EU. Derfor skal EU beskyttes mod især asiatisk unfair industriel konkurren- ce. Alle skal stå på lige fod i den globale konkurrence. Derfor skal en række krav om miljø og energisikkerhed, samt løn- og sundhedsforhold overholdes af ikke-europæiske virksomheder, der vil ind på det europæiske marked.

EU skal redde de skrantende virksomheder og investere i store industrier. Det kan kun ske, hvis der føres en fælles europæisk industripolitik, som især skal investere i kæmpe virksomheder, der producerer infrastruktur (les champions) - tilfældigvis en sektor hvor Frankrig har stor ekspertise.

I oktober 2008 - midt under finanskrisen - understregede Sarkozy, at det var EU's pligt at støtte produktion af skibe, biler, fly og tog, ellers ville europæerne vågne op en dag og opdage, at europæiske virksomheder var blevet solgt til ikke-europæisk kapital (Sarkozys tale i Europa-Parlamentet).

Sarkozys argumentation for beskyttelse af landbruget følger den samme logik som forsvaret for beskyttelse af europæisk/fransk industri. Store landbrugslande uden for EU skal følge de samme regler som europæisk landbrug. De skal overholde betingelserne for fødevaresikkerhed og bedre miljø. Sarkozy har sågar udtalt, at det ikke kan nytte at landmændene bliver udsat for miljøog social dumping, skatte og valutadumping.

Der må derfor sættes en grænse for dumping af fødevarer og den 
grænse skal sættes i WTO -forhandlingerne. Kun hvis det sker, kan landbrugssubsidierne fjernes.

Det beskyttende EU skal være en fast borg, hvor orden og autoritet stråler ud fra Bruxelles-centeret. EU skal være en stærk magt i en fragmenteret og globaliseret og dermed truende verden. EU skal tage kampen op med de store opkommende økonomiske magter Kina, Brasilien, Mexico, Indien og Sydafrika, hvis magtpotentiale skal 'inddæmmes'. Det skal gøres ved at udvide de otte store industrialiserede magters samarbejde (G8) til at inkludere de ovennævnte lande i de ottes klub, som dermed bliver til G13. Håbet er, at en sådan udvidelse vil medføre, at de nye opkommende økonomiske magter 'socialiseres' til et fair internationalt konkurrencesystem.

Visionen om et beskyttende EU kobles sammen med visionen om de stærke staters 'koncert' på globalt niveau. Frankrig tilskrives dermed en rolle på regionalt europæisk niveau som den magt, der kan drive EU fremad. Samtidig får Frankrig magt som stor suveræn stat på globalt niveau, hvor Frankrig sammen med andre store magter kan designe den fremtidige $\varnothing$ konomiske orden.

Denne vision slog Sarkozy fast i sin tale til de franske ambassadører den 27. august 2008, hvor han erklærede at "Frankrig bør være avantgarde i det europæiske projekt, lige så vel som Frankrig bør forblive en magt, som har en rolle at spille på verdensplan".

\section{Der må være en grænse}

Der skal også skabes grænser til de andre - til de illegale indvandrere. Lige fra dengang Sarkozy var fransk indenrigsminister (2002 - $2004 \mathrm{og}$ 2005 - 2007) og indtil det franske EU-formandskab har bekæmpelse af illegal immigration - især fra de tidligere franske kolonier i Nordafrika og i Afrika - været top-prioritet, hvad det også har været under det franske EU-formandskab.

På det europæiske topmøde i oktober 2008 blev det franske forslag om en immigrations- og asylpagt vedtaget uden vanskeligheder, da alle EU-landene i større eller mindre grad er interesseret i en fælles politik. Pagten bygger på en række EU-lovforslag, der er blevet vedtaget de seneste år. Formålet er at beskytte Europa bedre ved at kontrollere de ydre grænser, at organisere legal immigration på basis af hver enkelt stats evne til at modtage indvandrere, at organisere effektiv fjernelse af illegale immigranter, at etablere et asyleuropa samt hjælpe udviklingslandene økonomisk.

Under forhandlingerne lykkedes det ikke Frankrig at få en erklæring om forbud mod massiv legalisering af illegale indvandrere igennem. Spanien satte sig imod, fordi det siden 2005 har ført en storstilet legaliseringspolitik af illegale immigran- 
ter. Kompromiset blev, at det skulle være op til hvert enkelt land at bestemme omfanget af legalisering.

Der skal skabes en grænse til Tyrkiet, som Sarkozy og med ham en stor del af den franske befolkning ikke anser som europæisk. Det er et brud med Chirac, som af geopolitiske grunde var tilhænger af tyrkisk medlemskab. Imidlertid måtte Sarkozy indgå et kompromis, da han blev præsident. Han indvilligede i, at EU-forhandlingerne med Tyrkiet fortsatte. Til gengæld fik Sarkozy gennemtrumfet, at EU nedsatte en såkaldt reflektionsgruppe, der skulle komme med bud på, hvor EU's grænser skulle gå i fremtiden, samt hvordan EU-institutionerne skulle udvikles.

Men også i denne sag måtte Sarkozy gå på kompromis. Ingen ønskede, at refleksionsgruppen skulle beskæftige sig med de to ovennævnte emner. I stedet fik den mandat til at tale om alle mulige emner så som klima, terror, immigration, international kriminalitet samt en europæisk social og økonomisk model. Gruppen blev nedsat på topmødet i oktober 2008. Det er uhyre vanskeligt at forestille sig, at den får en stor betydning, da alle ovennævnte emner behandles i andre fora.

Skal der også skabes en grænse for yderligere EU-udvidelser? Det er en offentlig hemmelighed, at Frankrig ikke har været nogen varm tilhænger af EF/EU-udvidelserne. Hvis de ikke kunne undgås, skulle der først ske en uddybning af EU-institutionerne, som skulle sikre, at EU kunne blive en synlig og aktiv EU-aktør. Men pludselig i efteråret 2007 meldte Sarkozy, at Frankrig ikke længere ville modarbejde udvidelser med Balkan-landene.

Jean-Pierre Jouyet, minister for europæiske anliggender, erklærede i januar 2008, at Frankrig ikke havde gjort nok for at forstå nødvendigheden af udvidelser.

Her var der virkeligt tale om et brud i forhold til Mitterrands og Chiracs politik. Et sådant brud var muligt, fordi Lissabon-traktaten sikrede en uddybning og effektivisering af institutionerne. Nu er Lissabon-traktaten lagt på hylden. Sarkozy fremstiller sig dog stadig som fortaler for udvidelser. Men han er ikke altid lige klar i mælet.

I Polen under Georgien-konflikten erklærede han, at Ukraine nok skulle få EU-medlemskab på et eller andet tidspunkt. På EU-Ukraine topmødet den 9. september 2008 i Paris blev man enig om, at Ukraine skal tilbydes en ny samarbejdsaftale, der skal rykke Ukraine tættere på EU dog uden tilbud om EU-medlemskab. I Frankrig taler Sarkozy om, at der først skal ske institutionelle ændringer i EU, før nye udvidelser kan komme på tale.

\section{Middelhavsunionen}

EU skal beskyttes mod udefra kommende sikkerhedsproblemer. Til 
den ende lancerede Sarkozy i 2007 ideen om en Middelhavsunion, der skulle indbefatte de sydeuropæiske lande og de sydlige Middelhavslande. Formålet var at forhindre det sydlige Middelhav i at blive et yderligere sikkerhedsproblem for EU med et øget antal immigranter, risiko for terror-eksport til EU og øget forurening af Middelhavet.

Den ide faldt ikke i god europæisk jord. Det gjorde den ikke, fordi den udelukkede EU som aktør. Den blev betragtet som udtryk for en typisk fransk enegang. Angela Merkel vendte tommelfingeren nedad, og Frankrig var nødt til i marts 2008 at bøje sig for tysk krav om, at Middelhavsunionen blev til et fælles europæisk projekt, der ikke blev afkoblet Barcelona-processen, som blev iværksat i 1995 mellem EU, de arabiske lande omkring det sydlige Middelhav samt Israel.

Middelhavsunionen blev derfor omdøbt til Barcelona-proces: union for Middelhavet. Den blev lanceret den 13. juli 2008 som en vigtig prioritet under fransk EU-formandskab. Men det er vanskeligt at se, hvad nyt den skal bibringe i forhold til hidtidige middelhavsprojekter.

Sarkozy beviste i marts 2008, at han var i stand til at indgå et vigtigt kompromis med Tyskland nogle få måneder, før Frankrig stod for at overtage EU-formandskabet. Forslaget om Middelhavsunionen og forslaget om en reflektionsgruppe var udtryk for den deklaratoriske politik og mangel på forståelse for andre EU-landes interesser, hvad Parlamentsrapporten havde advaret mod. Sarkozy viste, at han var i stand til at tilpasse Frankrig til EU-formandskabet, som kræver, at formandslandet sætter egne interesser på standby.

Tilpasning er udtryk for Sarkozys pragmatisme. Han farer frem med forslag for at ruske op i EU. Derefter falder han ned for at få nogle reformer igennem. Men der ingen tvivl om, at Sarkozy vil fastholde kampen om et beskyttende Europa, der beskytter mod illegale immigranter, unfair dumping af varer, forurenende produkter og amoralske finanskapitalister.

Denne kamp giver mening på den franske nationale scene. Den giver også stadig mere mening på den europæiske scene bl.a. pga. finans- og økonomikrisen.

\section{Forsvarseuropa og NATO}

"Jeg er en ven af USA; men jeg vil, at EU fär et selvstandigt forsvar, for hvis vi $i k k e$ er $i$ stand til at forsvare os, så er vi $i k k e$ stand til at forsvare vor uafhengighed" (Sarkozys tale til det gaullistiske parti UMP, d. 12. januar 2008)

"Vi har behov for NATO og et europaisk forsvar. USA har behov for sterke allierede. Det faktum åbner op for, at Frankrig fornyr sit forhold til NATO" (Sarkozys tale ved NATOs topmøde, den 3. april 2008 i Bukarest)

Pragmatisk opbygning af et europæisk forsvar har haft top-prioritet 
under det franske EU-formandskab.

Frankrig satser på udvikling af følgende områder: 1) En revision af den europæiske sikkerhedsstrategi, som blev vedtaget i 2003; 2) en styrkelse af EU's militære kapaciteter, 3) et tættere samarbejde mellem de militært stærke lande samt 4) en udvikling af det indre marked for militært udstyr.

Med undtagelse af det første punkt, er de andre punkter gamle travere på EU's - og Frankrigs forsvarsdagsorden. Her er der er overhovedet ikke tale om et Sarkozybrud med fortiden - hverken med den franske eller den europæiske. Ikke desto meget mindre tales der i visse medier om, at Sarkozy bryder med franske forsvarstraditioner.

Det omtalte brud refererer til, at Sarkozy højt og tydeligt har erklæret, at Frankrig vil genindtræde i NATOs militære integrerede kommando. Helst allerede i april 2009, hvor NATO fejrer sin 60 års fødselsdag med topmøde i henholdsvis den franske by Strasbourg og dennes tyske naboby Kehl. Et symbolsk møde, som skal signalere, at ikke alene har Frankrig og Tyskland været forsonet siden Anden Verdenskrig; men at Frankrig, NATO og USA nu også er forsonede.

Sarkozys udmelding om nødvendigheden af fransk fuldt medlemskab af NATO har vakt ramaskrig blandt franske socialister, den yderste venstrefløj og blandt gamle gaullister. Sarkozy skældes ud for at være atlantist og amerikaner med fransk pas. Værre skældsord findes næsten ikke i Frankrig. Sagen er imidlertid, at han ikke er så meget atlantist, at han opgiver den traditionelle franske vision om et forsvarseuropa, som skal kunne optræde globalt og på lige fod med USA. Han er på linje med de Gaulle, når han udtaler med de Gaulles egne ord - at "Frankrig nok er allieret med USA, men ikke automatisk linet op bag amerikansk udenrigspolitik" (Sarkozys tale til de franske ambassadører den 27. august 2007).

Frankrig har lige siden terrorangrebet på World Trade Center i 2001 bakket USA's anti-terror krig op. Frankrig har fra første færd været til stede militært i Afghanistan og har sendt forstærkninger i sommeren 2008. Sarkozy støtter også amerikansk politik over for Iran. Men han er imod Irak-krigen og den amerikanske opfattelse af Syrien som en slyngelstat samt imod amerikansk utvetydig støtte til tyrkisk EU-medlemskab.

På NATOs topmøde i april 2008 modsatte Sarkozy sig også NATOs og USA's ønske om at give Ukraine og Georgien en Membership Action Plan (MAP), der er et forstadie til NATO-medlemskab.

\section{Kampen for klimaet}

Den udenrigspolitiske balancegang over for USA samt opbygning af et stærkt forsvarseuropa har været 
grundstrukturen i fransk sikkerhedsog forsvarspolitik. Sarkozy bryder ikke med denne struktur. Et andet kendetegn er, at Frankrig ikke på noget tidspunkt har sat spørgsmålstegn ved NATOs funktion som kollektiv forsvarsaktør. Det har været og er stadig modstander af et politisk stærkt NATO styret af USA. Det samme gælder for Sarkozy og hans forsvarsminister Hervé Morin.

Sidstnævnte har således udtalt, at "NATO kun skal være en militær alliance". Dette siges dog ikke helt så klart i den nye franske hvidbog for forsvar og national sikkerhed, som blev udgivet i juni 2008.

Ifølge hvidbogen spiller NATO en central rolle for europæisk og fransk sikkerhed. Samtidig understreges det, at fornyelse af NATO og styrkelse af europæisk forsvar går hånd $\mathrm{i}$ hånd. Der skal være komplementaritet mellem de to enheder. Det betyder - stadig ifølge hvidbogen - at NATO har behov for et EU, der skal påtage sig et større ansvar i stabilisering af eksterne kriser. EU har på sin side behov for et NATO, der er i stand til at sikre forsvarsmissionerne og styrke båndet til USA.

\section{To scenarier}

Hvidbogen advarer mod to ekstreme scenarier. Det ene er et scenario, hvor EU udelukkende er NATOs civile arm. Det andet er, at EU alene påtager sig det kollektive forsvar af sine medlemslande. Hvidbogen fo- reslår i stedet for disse to ekstreme positioner, at EU bliver NATOs privilegerede forsvarsaktør inden for både det civile og militære område.

En betingelse for at Frankrig indtræder i NATOs militære integrerede samarbejde er, at der skal ske en fornyelse (rénovation) af NATO. Hvad denne fornyelse skal bestå af, forbliver noget tåget. Forsvarsminister Hervé Morin har udtalt, at betalingen for fransk fuld indtrædelse i NATO er flere kommandoposter til Frankrig.

Det var også betingelsen for Chirac, da han i 1996 talte om nødvendigheden af en fornyelse af NATO i forbindelse med fransk deltagelse i NATOs Militærkomité, som Frankrig havde forladt i 1966. Chirac ville, at NATOs Syd-kommando skulle overtages af en europæer (læs: en franskmand). Fransk indtrædelse i NATOs integrerede militære struktur strandede dengang på amerikansk uvilje mod at give Frankrig mere indflydelse i NATO.

Spørgsmålet er nu, om USA har så meget brug for fransk militær og politisk styrke, at USA opgiver sin uvilje mod at give Frankrig mere indflydelse i NATO i form af kommandoposter. Det er også et spørgsmål, hvorvidt Frankrig vil frafalde sit krav om kommandoposter, fordi det har brug for at styrke NATO og få mere indflydelse i NATO.

Frankrigs fremtidige forhold til NATO og USA afhænger i meget høj grad af, hvordan den nye ameri- 
kanske præsident vil agere i verden. Vil den nye præsident følge devisen om, at det er missionerne, der bestemmer, i hvilke koalitioner USA vil indgå?

Hvis det er tilfældet, vil det vanskeliggøre yderligere uddybning af de franske relationer til USA og NATO. Hvis præsidenten derimod vil, at USA optræder som partner og ikke som leder af NATO, vil Frankrig i princippet kunne indtræde fuldt i NATO. Men det er ikke alene amerikansk politik, der afgør, hvorvidt Frankrig indtræder fuldt og helt i NATO. Den franske indenrigspolitiske diskurs om forholdet til NATO er også udslagsgivende.

De gamle gaullister, socialisterne og den yderste venstrefløj er bestemt ikke tilhængere af fuld indtrædelse i NATO. Det vil for dem betyde et politisk knæfald for USA. Ifølge dem vil Frankrigs forsvarsuafhængighed være en saga blot. Frankrig vil ophøre med at være en exceptionel nationalstat. Det er en myte, at Frankrig er forsvarsmæssigt uafhængig. Frankrig er dybt involveret i NATO - både finansielt og hvad angår operationelle missioner. Men myten lever. Og det bliver politisk vanskeligt at demontere denne myte.

Sarkozy skal han kunne påvise, at det politisk kan betale sig at være i NATO. Frankrig skal kunne erklære, at det ikke bare følger i hælene på amerikansk udenrigspolitik. Det skal kunne vise, at EU kan gøre en for- skel i EU's nærområde. Hvis ikke det sker, er det meget tvivlsomt, at modstanden forstummer.

Hvis det lykkes Sarkozy at få en revideret europæisk sikkerhedsstrategi vedtaget på EU-topmødet i december 2008, kan han hale endnu en sejr hjem. I Frankrig vil det være svært for modstanderne af hans forsvars- og sikkerhedspolitik at kritisere ham. På den europæiske scene vil han blive udråbt som en effektiv europæisk statsmand, der fik alle til at skrive under på en strategi, som alle kunne tilslutte til trods for yderst forskellige holdninger til USA og også til Rusland.

\section{Konklusion}

Der er ingen ende på begejstringen over Sarkozys handlekraft.

Kommentatorer og forskere udtaler, at det franske EU-formandskab er exceptionelt og en historisk begivenhed. Sarkozy har sat EU i bevægelse. Han har handlet hurtigt i kriser. Han har fået sat Frankrig i førersædet i EU. Det var også hans mål med det franske EU-formandskab.

Hvad vil der ske efter fransk EUformandskab? Sarkozy vil givetvis forsøge at få Frankrig til at fremstå som en drivende kraft under det tjekkiske og svenske EU-formandskab. Der er nok af problemer, der skal løses under de to formandskaber. Der er valg til det europæiske parlament i juni 2009. Der er et irsk 


\section{ULLA HOLM}

nej til Lissabon-traktaten - et irsk nej, der ifølge Sarkozy og de fleste andre europæiske statsledere skal vendes til et ja, og helst inden valget i juni.

Der er spørgsmålet om forholdet til Rusland, som ikke bare lige løses. Der er et NATO-topmøde i april 2009, som bliver af allerhøjeste vigtighed for fransk og europæisk fremtidig sikkerheds- og forsvarsstrategi. Der vil være en økonomisk krise, som kræver nytænkning af forholdet mellem stat, samfund og EU. Sarkozy vil sikkert med ildhu kaste sig over alle problemerne. Hvordan han vil kaste sig selv og Frankrig ud på den europæiske og globale scene vil i vid udstrækning afhænge af, hvorvidt Lissabon-traktaten vedtages.

Hvis den ikke bliver det, vil Sarkozy sikkert føre gaullistisk politik. Han vil forsøge at danne ad hoc alliancer med andre store lande. Hvis den bliver vedtaget, bindes Frankrig institutionelt så meget, at det snarere vil være den mitterrandske vision om et fordoblet Frankrig på EU-niveau, der vil være den dominerende franske EU-model.

Ulla Holm er seniorforsker ved DIIS (Dansk Institut for Internationale Studier)

Artiklen er skrevet fardigt 30. oktober.

\section{Udvalgt litteratur}

"Direction de l'action du gouvernement. Présidence francaise de l'Union européenne", Assemblée nationale, au nom de la commission des affaires étrangères, no 279 , tome V1,11.10.07.

U. Holm (2006):Det gamle Frankrig i det nye Europa. København: DIIS.

U. Holm (2007): "Sarkozy: Et stærkt Frankrig i et effektivt EU", Udenrigs, nr 2, ss. $75-86$.

A. Juppé, L. Schweitzer (red.) (2008): La France et l'Europe dans le monde. Livre blanc sur la politique étrangère et européenne de la France. 2008 2020. Paris, La documentation francaise F. Mitterrand (1986): Réflexions sur la politique extérieure de la France. Paris: Fayard.

N. Sarkozy (2007): Ensemble. Paris: X0 éditions Le livre blanc sur la securité et la défense, juni 2008. Paris: Odile Jacob. 